\title{
VIABILITY OF ISLAMIC BANKING AND FINANCE IN SOUTH AFRICA: A LOOK AT THE LEGAL FRAMEWORK AND GOVERNANCE
}

\author{
Moegamat Igshaan Taliep, ${ }^{*}$ \\ Rusni Hassan ${ }^{* *}$ \& Adnan Yusoff***
}

\begin{abstract}
South Africa has a total Muslim population of more than 1 million people representing 2.1\% of total population (Islamic Finance News, 27th October 2010), thus creating the demand for Islamic banking and finance. Though the concept of Islamic banking in South Africa can be traced back to several decades, the practical implementation only started in late 1980s with slow initial start up. Presently, while the industry is relatively modest in term to figures, Islamic banking is strategically important for economic development of the country. South African Islamic banking is set to expand at a rapid rate as the new players identify huge opportunity in the country. However, Islamic banks face a series of challenges in the South African market. Increasing
\end{abstract}

\footnotetext{
* Lecturer, International Peace University of South Africa (IPSA), Cape Town, South Africa.

** Assistant Professor, Islamic Law Department, Ahmad Ibrahim Kulliyyah of Laws, International Islamic University Malaysia.

Lecturer, Centre for Islamic Studies and Civilisation, Universiti Tenaga Nasional, Malaysia.
} 
competition, education and awareness, and legal framework are the significant challenges for all institutions in the Islamic banking markets. This paper looks at the challenges of the legal framework and governance in implementing Islamic banking and finance in South Africa.

Keywords: Islamic banking and finance, South Africa, legal framework, governance, regulation.

\section{INTRODUCTION}

During the last two decades the South African financial and economic arena has seen Islamic Sharī'ah permeate its horizon with various Sharī'ah compliant products on offer. The success of Albaraka Bank Limited, a member of the Saudi-based Dallah Albaraka Banking Group, led to Islamic windows being opened at major South African banks. This includes First National Bank Islamic Finance and Absa Islamic Banking.

The equities market in South Africa now boasts at least four Sharī'ah compliant unit trust funds (Oasis Crescent Equity Fund, Futuregrowth Alabaraka Equity Fund, Frater Islamic Unit Trusts and Stanlib Sharī ah Fund) as well as Islamic Pension or Provident Funds (Oasis Crescent Provident Fund, Old Mutual Pristine Provident / Pension Funds and the Old Mutual Symmetry Fund). TakafolSA offers short term insurance products, on the basis of mutual assistance, the only option currently available. South Africa is thus currently serving as the hub for Islamic Banking in Southern Africa which includes Botswana (First National Bank has an Islamic banking window there).

This paper focuses on the viability of Islamic banking and finance (IBF) with specific reference to the current South African legal framework. It sets out to accomplish this task by reflecting on the origins of the IBF landscape in South Africa. Consequently, this instalment of IBF history focuses on two significant pioneering projects, Jaame Investment Ltd and Islamic Bank Ltd, both of which, regrettably, ended in failure. Thereafter, focus is shifted to a somewhat restorative phase in IBF development with the advent of Albaraka Bank Ltd in South Africa. From humble beginnings, although the number of branches remained 
static, its operations witnessed progressive growth ever since its inception in 1990. Owing to its endurance, resulting in a boost of confidence for IBF in South Africa, some major conventional banks forayed into the realm of IBF by opening Islamic banking windows. At the same time, significant growth occurred in the equities market with the meteoric rise of Muslim-owned Oasis Asset Management. Their Oasis Crescent portfolio afforded the Muslim public the opportunity to invest in a range of Shari '`ah compliant products and experience phenomenal growth. A number of other unit trust products, including Futuregrowth-Albaraka, also appeared on the market. A focussed attention on the equities market, for present purposes though, falls beyond the purview of this paper.

Although, to date, no specific legislation on IBF is extant, the recent introduction of the Financial Intelligence Centre Act (FICA), 2001 (Act No. 38 of 2001) and Financial Advisors and Intermediaries Services (FAIS), 2002 (Act No. 37 of 2002) have certainly enhanced legal dimensions of IBF operations in South Africa. There are numerous other acts, in addition, regulating conventional banks and financial institutions that directly impact on IBF role-players. Needless to say IBF clearly benefits from the highly regulated environment of the sophisticated banking sector in South Africa. However similar regulatory mechanisms in relation to Shar $\iota^{`} a h$ Advisory Boards do not exist. Some reflections in this regard are forwarded. This dearth, notwithstanding, IBF institutions are required to operate under the aegis of a number of statutory bodies whose mandates vary, but inevitably include oversight of some aspect or the other.

Such interaction with statutory bodies, aided by the phenomenal growth in IBF internationally has resulted in the cross-pollination of thoughts. To a large extent, IBF discourse has started to take root in the banking and finance regulatory sector in South Africa. Some of the recent developments in this regard are raised. Already certain challenges have been overcome, but still others remain. Many of these were discussed at historic meeting convened, recently, for IBF institutions by the Treasury Department of the South African Reserve Bank. In conclusion, some further reflections on the development of IBF in South Africa are registered. 


\section{A CHRONOLOGY OF IBF IN SOUTH AFRICA}

What follows is an attempt at a chronology of IBF in South Africa commencing with the pioneering efforts of the now defunct Jaame Investment Ltd. The origins of this first IBF project in South Africa were distinctly community orientated. At the time when Jaame Investment Ltd declined towards its eventual closure, Islamic Bank Ltd emerged to fill the void. This ground-breaking project to provide Islamic banking and finance as an alternative, however, did not succeed and had to end the operations. The only Islamic Bank currently, Albaraka Bank Ltd, slowly managed to restore the dignity of Islamic Banking and Finance in South Africa.

\section{Pioneering Islamic banking institution - Jaame Investment Limited}

Pursuant to its founding philosophy of 'Islām as a way of life' the Muslim Youth Movement of South Africa (MYM) in 1976, registered Jaame Investment Ltd, a financing company, with the stated objective of promoting the principles of Islamic economics and striving for an interestfree Muslim society. The primary aim was the uplifting of the Muslim ummah as a whole through the implementation of Islamic economic principles.

Four years later in 1980, Jaame Investment Ltd was floated as a public company with 2500 shareholders, offering the general Muslim public an opportunity to participate. The overriding motivation was to provide some alternative to the prevailing interest system; the idea was never to compete with banks and building societies. From a legal framework perspective, therefore, Jaame functioned under the auspices of the Companies Act 1973 (Act No. 61 of 1973), and not the Banks Act 1965 (Act No. 23 of 1965). Although the regulatory regime prescribed in accordance with the Companies Act is itself rigorous, it naturally does not purport to provide the regulatory standards necessary for a monetary environment as contemplated in the Banks Act 1965.

The chief activities through which Jaame sought to execute its vision included the purchasing of vehicles, goods or equipment at cost with the view to sell to clients on the basis of Muräbahah (cost plus profit sale). Investing capital in viable business on a joint venture and 
profit-sharing basis, or Mushärakah (partnership), was another mechanism employed. ${ }^{1}$

Jaame Investment Ltd established its head office in Johannesburg with branches in Cape Town and Durban. Tayob notes that perhaps due to the Islamist nature of the MYM 'fellow workers and financial planners were selected from dedicated MYM members, often at the expense of economic acumen or training.'2 After a while Jaame was subjected to severe pressure based on allegations of un-Islamic business dealings. In 1988 Jaame directors solicited an interdict to prevent the distribution of pamphlets which alleged various irregularities. It was claimed that the organisation dealt in interest, that the AGM was marred by irregular voting procedures, and that the board of directors acted in violation of shareholders' interest. Whilst, initially, the MYM stood by its directors deeming the allegations nothing but a smear campaign, it came to light that the Johannesburg office was involved in questionable business activities. A commission of inquiry failed to secure exoneration, resulting in an increase in withdrawal of funds. When the operations were eventually closed in 1989, the Islamic Centre Trust, formed by the MYM in 1978, raised funds to pre-empt liquidation. Key contributing factors to the erosion of sound business principles were the advancement of personal loans for high-risk retail ventures with inadequate guarantees and collateral; recurring advances to individuals despite bad track-records of repayment, etc. However, Muslims across the country also viewed Jaame as a chance to obtain finance easily. ${ }^{3}$ The pioneering initiative to create a consciousness of an alternative form of economic transactions may be said, at best, to have left the community ambivalent, and at worst, engendered a deep scepticism of Islamic banking and finance.

$1 \quad$ Mahida, Ebrahim Mahomed: A History of Muslims in South Africa, a Chronology [on-line] available: http://www.sahistory.org.za/pages/ library-resources/online\%20books/history-muslims/1970s.htm, accessed 6 March 2010 Cf. Jaame Journal Annual Report, 1985-1986; Johannesburg, Jaame Limited; Post Natal, Durban, December 7, 1983.

2 Tayob A K: Islamic Resurgence in South Africa: the Muslim Youth Movement Cape Town: UCT Press 1995, p. 180.

3 Tayob A K: Islamic Resurgence in South Africa, p. 181. 


\section{South Africa’s first Islamic bank - Islamic Bank Ltd}

The second attempt at providing the South African Muslim community with a halāl alternative to save and invest their disposable income occurred about the time when the Jaame project entered its period of decline. The Islamic Corporation Limited (ICL) applied to the South African Reserve Bank for a banking license on 07 April 1981, but was refused. On 03 September 1982, after a second application, the Ministry of Finance granted ICL the approval for the formation of a company "to receive investments from Muslims only." The ICL was given limited banking status which restricted it to accept deposits for a minimum period of five years. The ICL was thus the first banking institution of its kind in southern Africa and it commenced operations in Johannesburg in 1983. The bank was founded on the Islamic principles of usury/interest-free economy and provided Muslims with an alternative to interest-based accounts at conventional banking institutions.

The ICL operated with a capital base of R200 000-00 (Two Hundred Thousand Rand) at its inception and by 1988 its assets exceeded R12 million. On 29 September 1988 after eleven attempts to procure a banking license, the South African Reserve Bank granted approval for the Islamic Corporation Limited to be registered as a banking institution and the ICL was renamed the Islamic Bank Limited (IBL). The bank's core activity was to attract depositors for savings and to advance these monies for the purpose of assisting individuals/businesses with their financing needs. In terms of Islamic law the profits earned on the markup in respect of the financing transactions have to be shared between the depositors and shareholders on an agreed ratio but recognised over the period of the transaction. In this regard the bank was obliged to comply with Generally Accepted Accounting Practice (GAAP) and with the Companies Act No. 61 of $1973 .{ }^{4}$

In 1997 it was alleged that the bank lost the confidence of its depositors and shareholders because the management and the nonexecutive directors of IBL appeared to be unfit to run a bank in that they did not act in the best interests of depositors. They were also said to have contravened sections 72, 73 and 74 of the Banks Act, 1990 (Act

$4 \quad$ Mahida E M: A History of Muslims in South Africa, published by Arab Study Circle (South Africa) 1993. 
No. 94 of 1990), i.e. by not complying with the minimum liquid asset requirement; failing to report its large exposures and failing to comply with prudential requirements as stipulated by the Companies Act, 1976 (Act 61 of 1976). Allegedly, there was also misrepresentation of the bank's financial position in that it had failed to keep up to date accounting records. Apparently the Bank further failed to comply with the corporate governance code of conduct in terms of the "King Report of Corporate Governance 1994.” Finally, in addition to all of the above, the Registrar was deeply concerned about the bank's non-compliance with the minimum liquid asset requirements and IBL's failure to meet its obligation to the conventional commercial bank. All of which, in turn, appeared to be the result of poor quality of risk management; inadequate systems and controls; poor cash flow management; and the inability of IBL to dispose of its non-performing assets. As a result of this appalling state of affairs an independent investigation was instituted by the South African Reserve Bank (SARB). ${ }^{5}$

The worst fears of the Muslim public who invested their life savings and organizational funds in IBL were materialized. The relevant report by the Registrar of Banks and General Manager, Bank Supervision, SARB represents the official historical record of the liquidation of the first Islamic bank in South Africa and the attendant causes and circumstances leading thereto. This report is cited below:

As part of the Bank Supervision Department's ongoing process of obtaining and analyzing information on Islamic Bank Limited "IBL," the South African Reserve Bank "the SARB" appointed two SARB employees as inspectors, in terms of section 11 of the South African Reserve Bank Act, 1989 (Act No. 90 of 1989 - "the SARB Act”), in order to obtain financial information on IBL from sources other than IBL itself. The information gathered by these inspectors indicated that an urgent independent inspection of the affairs of IBL had to be undertaken. Two independent chartered accountants

$5 \quad$ Nakhooda Y: Based on unpublished Masters thesis on Investigation into the collapse of Islamic Bank Ltd, p. 53. 
were therefore appointed by the SARB, again in terms of section 11 of the SARB Act, to perform such an inspection at the premises of IBL. Following their inspection, the inspectors presented the Registrar of Banks with a report, which indicated that, as at 199709-30, IBL was insolvent.

Having regard to IBL's circumstances, the only just and equitable option available to the Registrar was to apply to a competent court for the winding-up of IBL. Consequently, on 21 November 1997, the Registrar, in terms of section 68 of the Banks Act, and with the approval of the Minister of Finance, lodged an urgent application in the High Court of South Africa (Transvaal Provincial Division) for the winding-up of IBL. The bank did not oppose the application, and, on the same date, the High Court granted an order that IBL be placed in provisional liquidation and appointed a provisional liquidator to the bank. At the same time, a rule nisi was issued, calling upon IBL to show cause, if any, on or before 1998-01-13, why the provisional liquidation order was not to be made final. On that date, the High Court granted an order, whereby IBL was placed in final liquidation, and the provisional liquidator was appointed as final liquidator to the bank.

Having regard to the financial position of IBL, it became clear that depositors in the bank would suffer financial loss. In the absence of any form of depositinsurance protection in South Africa, the Minister of Finance and the SARB, in the interest of the financial stability of the country, announced that the SARB would compensate the loss of all depositors in IBL up to a maximum amount of R50 000,00 per individual depositor, subject to appropriate conditions. This arrangement should, however, not be seen as creating a precedent. ${ }^{6}$

$6 \quad$ Wiese C F: Registrar of banks, Banking Supervision Department [online] available: http://www.resbank.co.za/bsup/ann97/chapter1.html, accessed 06 September 2008. 
This report ends another poignant episode of unsuccessful initiative to introduce and operating Islamic banking and finance in South Africa. The liquidation of the IBL was the illustration of the frustration of the Islamic banking players to operate Islamic banking and finance in unfamiliar legal framework.

\section{Full fledged Islamic bank - Albaraka Bank Limited}

The current South African Commercial Banking landscape only sports one fully fledged Islamic bank. Albaraka Bank Limited in South Africa was established under the terms of the Banks Act 1965 (Act No. 23 of 1965) with registered offices in Durban and officially opened in March 1990. The authorised capital of the Bank was Rand 10 million. Of this capital, 50\% was held by the Jeddah-based Albaraka Investment and Development Company, the rest by local investors. ${ }^{7}$ Financial results released for the year to end-December 2007 show taxed profits up 84.5\% to $\mathrm{R} 18.2 \mathrm{~m}$, nearly double the previous financial year, and advances growing by $43.1 \%$ to R1.31bn. The bank currently has more than 3,000 Mushārakah deals. ${ }^{8}$

As mentioned before and to be discussed closer later on, the existing legal framework in the country does not make any specific accommodation for IBF principles and transactions. The extent to which Albaraka Bank secures legislative acceptance of its products and services depends on the effectiveness with which it mobilises the law of contract. This means that the law of the land does not clearly stipulates the behaviour and the nature of Islamic banking products and operation of it; but it is the responsibility of the first Islamic bank in South Africa to crystallize the relationship between it and the customer in form of contract; so that everything which happens between the bank and the customer could be enforced in court under the Law of Contract.

\footnotetext{
$7 \quad$ Albaraka Bank: [on-line] available: http://www.albaraka.co.za, accessed 13 September 2008.

8 Albaraka Bank Annual Report 2007, [on-line] available: http:// www.albaraka.co.za, accessed 13 September 2008.
} 
In a similar manner to which the courts are prepared to give effect to the patrimonial consequences of an Islamic marriage because it is based on contract, whilst not officially acknowledging the marriage, the effects of IBF products are enforceable provided that the underlying contracts legally stipulate the necessary requirements.

To achieve the required measure of Islamicity in the formulation of IBF contracts, the latter is drawn up by a team of experts including a legal expert, a Sharī'ah scholar, an accountant and an IT specialist. The purpose of the legal review is precisely to ensure that the contract will stand in a court of law. An external review is conducted, in addition, to confirm its legality and to test for loopholes. All contracts include a first level judicial enquiry via previous arrangement with mediation and arbitration departments of informal judiciaries such as the Jam 'iatul 'Ulam $\bar{a}$ ' or Muslim Judicial Council. If through that process a resolution cannot be achieved, the parties retain the right to initiate proceedings at the appropriate Court based on the value and nature of the case. ${ }^{9}$

As part of the Sharī ah governance requirement, Albaraka Bank has appointed its Sharī'ah Supervisory Board which comprises three scholars of distinction. ${ }^{10}$ It is quite clear that Albaraka Bank, like other players in the field, carefully selects scholars of eminent qualification to serve on its Board. Their eminent reputations probably play a significant role to induce confidence with regard to the Sharī'ah compliant status of products in the mind of the Bank's clientele. The Bank observes a policy of transparency and accountability by its Sharī'ah Supervisory Board by way of its Sharīah Report to the shareholders of Albaraka Bank in its Annual Report. According to the most recent Annual Report 2007, the Sharī'ah Supervisory Board expressed their independent opinion based on a review of the banks operations. In their view, the transactions,

$9 \quad$ A curious case currently raised by Albaraka continues sub judicae against a client who summarily stopped repaying, after two years, a mortgage on the basis of a muräbaḥah sale claiming that it was not Sharī'ah compliant. Interview: Mohamed Z, CEO Islamic Finance Institute of South Africa, IFISA (former Product Developer Albaraka bank), 28 August 2009.

10 It is headed up by the internationally renowned Dr Abdus Sattar Abu Ghudda from Syria along with Adv. Mohamed Shoaib Omar and Mufti Shafique Jakhura, locally. 
contracts and dealings entered into by the bank during the year of review generally complied with the principles and rules of Sharī'ah, subject to some observations of an operational nature, for example, "In certain cases... relevant documentation relating to Sharī'ah compliance were not available at the time of the audit" citing "inadequate filing." 11 The overall tone of the report, though, is positive.

\section{Conventional banks with Islamic banking windows}

Over the past few years two of the five major banks in South Africa, namely First National Bank and ABSA responded to the growth in demand for Islamic finance and banking products by launching their own Islamic windows in 2004 and 2006, respectively. The launch range of products was relatively modest in comparison with their conventional offerings. First National Bank started off by affording Muslims the opportunity of obtaining vehicle finance through its relevant division, Wesbank. Product offerings subsequently expanded to include a cheque account, a debit card, youth accounts, home loans, personal loans and commercial property loans. Today, First National Bank Sharī‘ah compliant finance bank accounts are available at any of the more than 650 First National Bank branches around the country and meet the needs of youth, sole proprietors and business customers. ${ }^{12}$

ABSA similarly offered a limited number of products with its launch. This included, and remains confined to a cheque account, vehicle and asset financing based on ijärah, savings and investment account options and an Islamic will service. It offers phone, internet and branch banking. ABSA Islamic Banking is part of the ABSA Group nationally, as well as the Barclays Group internationally. Like in the case of First National Bank, the distinct advantage that the Islamic banking windows of conventional banks offer clients is sheer reach through their vast network of branches in the country and abroad. According to the Chief

\footnotetext{
11 Albaraka Bank Annual Report 2007, pp.32-33 [on-line] available: http:/ /www.albaraka.co.za.

12 Patel E: CEO First National Bank Islamic Finance [on-line] available: https://www.fnb.co.za/news/archive/2006/20060627shariah.html, Accessed 6 March 2010.
} 
Executive Officer, Moola, new product developments under the strict supervision of its Sharī'ah Advisory Board members will shortly include a home loan, amongst others. The Sharī'ah Advisory Board is similarly responsible for all aspects of compliance and delivery of new products. ${ }^{13}$ In an interview with an ABSA Sharī'ah Advisory Board member, it is confirmed that whilst the board deems itself bound to maintain AAOIFI standards as a minimum, it functions as an autonomous group. ${ }^{14}$ In the final analysis, therefore, it is their reputation as scholars of note that ultimately commands public acceptance of the products and services they oversee.

\section{SHARI' 'AH ADVISORY BOARDS AND LEGAL FRAMEWORK}

Islamic banking and finance players in the market today generally place a high premium on the reputation of their Sharī'ah Advisory Board members. Arguably, this fact in itself contributes significantly to enhance the legitimacy of their products and to gain the confidence of the public. It may safely be maintained that the individuals who currently serve in Sharī'ah advisory capacities have established their scholarly, as well as reputational worth in the academic landscape of the Muslim community. Here and there, there are also high profile foreign scholars who occupy position on Sharī'ah Advisory Boards of some institutions, but those are exceptions. Because of the fact that, to date, there has been no specific accommodation in legislation for the growing IBF sector, Sharī'ah Advisory Boards enjoy reputational standing as opposed to legislative sanction.

It shall be noted here that the legislature is reluctant to enact a separate piece of legislation which would be comprehensive enough to cover both substantive and the procedural laws of Islamic banking in one. This is another dilemma which will exacerbate in future years if no

13 Moola A: CEO ABSA Islamic Banking [on-line] available: http:// www.absa.co.za/absacoza/content.jsp?VGN_C_ID= 1edf058d79d09110 VgnVCM1000003511060aRCRD\&VGN_CI_ID=576006. be9f941110VgnVCM1000003511060aRCRD, Accessed 6 March 2010. Karaan T: Member ABSA Sharī‘ ah Advisory Board, Interview date: 3 September 2009. 
positive action is taken to overcome it. It is vital and imperative to stipulate the conditions of the Sharī'ah scholars who preside on the Sharīah Advisory Boards as they are the watchdogs of the Islamic banking whose main function is to protect Islamicity in Islamic banking products.

It is precisely this status quo that prompted the United Ulema Council of South Africa (UUCSA) to commission a task team to propose a regulatory framework for the IBF sector, including the functioning of Sharī ah Advisory Boards. And although a substantial presentation (395 pages) proposing the South African Islamic Financial Services Authority (SAIFSA) to the plenary session of 23 November $2005^{15}$ held at the offices of the Muslim Judicial Council in Cape Town evoked positive response, the debate which ensued over the succeeding months revealed high levels of resistance to the formation of an over-arching structure particularly from persons and institutions who until then have been playing a significant role in the realm of IBF. Albeit that many plausible motivations of cautious nature were forwarded too, the opportunity of history to form a regulatory framework ought to have prevailed. Instead, the voice of progress was silenced for narrow and parochial considerations.

Of certainty, even those who stood in opposition to the formation of a transparent and accountable public IBF regulatory framework must accede that the current informal status quo may sooner rather than later stand rejected in a society where especially monetary matters, as a norm, have become highly regulated. Also, it will be a travesty if the reputation of the very persons who are presently endorsing IBF operations and products become increasingly exposed. The question is how to overcome this challenge? For the moment, at least, whilst the SAIFSA experience is still fresh in the minds of the 'ulam $\bar{a}$ ', perhaps the industry ought to petition the SARB to initiate a process for the regulation of Shari' $a h$ Advisory Boards.

Some of the relevant legislative provisions in Malaysia could be followed as guidelines. There ought to be no good reason why the SARB Act does not provide for the formation of a Shari ‘ah Advisory Council (SAC) similar to that of the Central Bank of Malaysia. ${ }^{16}$ For the composition of the SAC it may prove useful to maintain a healthy blend

United Ulema Council of South Africa (UUCSA): National Financial Regulatory Board Minutes of Meeting, 23 July2005: Source Patel Y, Secretary General.

$16 \quad$ See Part VII of Central Bank of Malaysia Act 2009. 
between national and international experienced personas. Since there appears to be an inclination to AAOIFI standards on the part of existing Sharīah Advisory Boards, local scholars may find the acceptance of the binding authority of the proposed SAC palatable. The SAC could play an important role on behalf of the SARB to evaluate applications for the establishment of new IBF operations. A measure that may further enhance the legal standing of Sharī'ah advisory bodies could be the introduction of a provision in the Banks Act 1990 similar to section 3(5) of the Islamic Banking Act 1983 in Malaysia. Sub-section (b) provides that "The Central bank shall not recommend the grant of a licence, and the Minister shall not grant a licence unless the Central bank, or the Minister, as the case may be, is satisfied that there is in the Articles of Association of the bank concerned provision for the establishment of a Shari 'ah Advisory Board, as may be approved by the Central Bank, to advise the bank on the operations of its banking business." ${ }^{17}$ The outstanding requirement at present is to formalise the functioning of Sharī'ah Advisory Boards and the aforementioned proposals could possibly accomplish that.

\section{LEGAL FRAMEWORK OF ISLAMIC BANKING AND FINANCE IN SOUTH AFRICA}

Notwithstanding the paucity of regulation at present with regards to Sharī'ah Advisory Boards per se, the South African banking regulatory framework in itself, on the other hand, ensures a rigorous environment of financial accountability, transparency and legitimacy starting from the supreme law of the Republic, the Constitution, in light of which all law have to be interpreted.

\section{Constitution of the Republic of South Africa, 1996 (Act No. 108 of 1996)}

To reiterate, there is currently no legislation or amendments to any legislation that caters specifically for IBF in South Africa. All 
legislation however is governed by the Constitution of the Republic of South Africa which was adopted on 8 May 1996. It is the supreme law of the land. No other law or government action can supersede the provisions of the Constitution.

In addition to guaranteeing the right to freedom of conscience, religion, thought, belief and opinion, s. 22 of the Bill of Rights also entrenches every citizen's "right to choose their trade, occupation or profession freely." It states further that "the practice of a trade, occupation or profession may be regulated by law." ${ }^{18}$ Therefore the right to appropriate regulatory mechanisms required for IBF as is the case with conventional banking finds clear sanction in the highest law of the land. Pertaining to property rights the Constitution states that " $[\mathrm{N}] \mathrm{o}$ one may be deprived of property, except in terms of law of general application." 19 The "law of general application" includes a priori the law of contract. Thus as long as IBF contacts are well-structured towards achieving their objectives, the courts will enforce and uphold the intent of the contracting parties to the extent of the provisions of contract . But this does not mean that the conventional banks can engage in trade based activities. Legal academicians opine on this question as follow:

"In the context of delictual and contractual claims the Constitutional Court and the Supreme Court of Appeal have held that the duty of the Courts to develop the Common law in terms of the Constitution and its underlying values extends directly to the principles and the concepts of the positive law. Therefore the Constitution apparently is and should be interpreted as having application also to contracts. ${ }^{20}$

18 Constitution of the Republic of South Africa 1996 (Act No. 108 of 1996): JUTA Law $20064^{\text {th }}$ Edition, p. 10.

19 Constitution of Republic of South Africa 1996: s. 25, p. 11.

20 Van Der Merwe S., Van Huysteen L.F, Reinecke M.F.B, Lubbe G.F: Contract General Principles Lansdowne: JUTA Law $2^{\text {nd }}$ Edition 2003, p. 13. 


\section{South African Reserve Bank Act 1989 (Act No. 90 of 1989) and Banks Act 1990 (Act No. 94 of 1990)}

Of the most important functions of the Reserve Bank is bank regulation and supervision in South Africa. The purpose is to achieve a sound, efficient banking system in the interest of the depositors of banks and the economy as a whole. This function is performed by issuing banking licences to banking institutions, and monitoring their activities in terms of either the Banks Act, 1990 (Act No. 94 of 1990), or the Mutual Banks Act, 1993 (Act No. 124 of 1993). ${ }^{21}$ The Bank Supervision Department of the Reserve Bank headed by the Registrar of Banks perform its important task in accordance with the relevant provision of the Banks Act, 1990 (Act No. 94 of 1990). Section 90, in particular, of the Banks Act provides the basis for the comprehensive and rigorous set of 'Regulations relating to Banks.' The extent of these regulations has been tabulated in the Government Gazette of 1 January 2008. The various chapters focus on the basis of the regulations to the financial, risk-based and other related returns, to corporate governance, to application procedure, to information required by Registrar and research department of the Reserve Bank, etc. ${ }^{22}$

Further, yet equally important regulatory mechanisms in the Banks Act, 1990 are provided in sections 60A and 60B pertaining to compliance function and corporate governance, respectively. The purport of these provisions relate to the infrastructural integrity of banking institutions in the country, including, naturally, the one Islamic bank and the two Islamic window operations of First National Bank and ABSA. In fulfilment of the provisions of sections $60 \mathrm{~A}$ and $60 \mathrm{~B}$ the directors of Albaraka Bank Ltd have set out in detail its Corporate Governance declaration on pages 16 to 26, and the Compliance Report on pages 29 to 30 of its Annual Report 2007. ${ }^{23}$ Under the section on compliance is included Albaraka's declaration on money laundering control and

\footnotetext{
21 South African Reserve Bank: [on-line] available www.resbank.co.za accessed 13 February 2010.

22 Government Gazette Republic of South Africa Pretoria: No. 30629 vol. 511, 1 January 2008.

23 Albaraka Bank Ltd Annual Report 2007, [on-line] available: http:// www.albaraka.co.za.
} 
combating of terrorism legislation, fulfilment of requirements as stipulated in accordance with the Financial Advisory and Intermediary Services (FAIS) Act, 2001, its ongoing observance of the Code of Banking Practice, conformity with the provisions of the National Credit Regulator under the National Credit Act, 2005, etc. ${ }^{24}$

The Banking Supervision Department has traditionally placed a high premium on its relations with an important counterpart in the monitoring and regulation of banks, viz. the independent auditing profession. S.61 of the Banks Act 1990 places a legal responsibility on banks to obtain the approval of the Registrar pertaining to the appointment of auditors. S.63, on the other hand, provides the basis for the functions of auditors in relation to the Registrar. Whilst it proceeds to confirm the duties on the auditor in terms of the Auditing Profession Act, 2005 (Act No.26 of 2005) and the Companies Act, 1973 (Act No. 61 of 1973), it adds certain obligation on the auditor to report directly to the Registrar with reference to any irregularities that are discovered during the course of an audit. ${ }^{25}$ To this end the Registrar maintains a close working relation with the South African Institute of Chartered Accountants and the Independent Regulatory Board for Auditors.

From the aforementioned, it can be clearly seen that any IBF institution in the South African Banking sector may find the regulatory framework enabling the maintenance of exemplary levels of corporate governance, transparency and accountability.

\section{Financial Intelligence Centre Act (FICA) 2001 (Act No. 38 of 2001)}

As pointed to above, FICA has not only brought about a national mind-shift in the way people do banking, but it literally permeates all financial transactions and dealings in the country. Through the process of assent of this act by the President, a Financial Intelligence Centre and a Money Laundering Advisory Council was established to combat money laundering activities, and to impose certain duties on institutions and other persons who might be used for money laundering purposes. Included in

\begin{tabular}{ll}
\hline 24 & Ibid. \\
25 & Banks Act 1990 (Act No. 94 of 1990).
\end{tabular} 
the mandate of these organs is to maintain conformity and effect amendments to the Prevention of Organised Crime Act, 1998, and the Promotion of Access to Information Act, 2000. The composition of the Money Laundering Advisory Council ensures a multi-faceted approach between government structures; it includes the Governor of the Reserve Bank. ${ }^{26}$

In terms of FICA, all regulated institutions, such as banks, have specific duties to help prevent and report on money laundering. FICA facilitates this process by creating and prescribing money laundering control obligations for banks and other institutions and professionals, such as estate agents, brokers, attorneys and insurance companies.

\section{The Financial Advisory and Intermediary Services (FAIS) Act (Act No. 37 of 2002)}

Due to increasing concerns about the quality of financial advice within the financial services industry, the Ministry of Finance, has since the 1990s, investigated mechanisms for regulating conduct within the financial services industry. FAIS aims to regulate the giving of advice and rendering of intermediary services to clients, as well as certain other issues. The Act impacts on financial institutions, financial service providers, including Islamic Banks and their staff. To this end, continuous staff development and certification is prescribed. According to their Annual Report 2007, Albaraka Bank reported on its development programs and policies for the year under review and declared its continued commitment to the requirements of the FAIS legislation. ${ }^{27}$

\section{Regulatory organs on IBF in South Africa South African Reserve Bank (SARB)}

The SARB has, to date, made no specific amendments to legislation to provide for IBF, but moves are currently afoot to accommodate Islamic banks and financial institutions in the South African

$\begin{array}{ll}26 & \text { Financial Intelligence Centre Act (FICA) } 2001 \text { (Act No. } 38 \text { of 2001). } \\ 27 & \text { Albaraka Bank Annual Report } 2007 \text { p. } 29 .\end{array}$ 
legal framework. The Treasury Department of the SARB had a meeting with all the stakeholders in June 2008. The purpose of the meeting was to explore ways in which to remove impediments to the effective implementation of Islamic Banking in South Africa. The meeting took place at the Pretoria offices of the Treasury Department. Stakeholders in IBF were asked to submit reports outlining their needs and difficulties. ${ }^{28}$ Clearly, SARB must be realising that unless all efforts are expended to facilitate a regulatory framework that is seen to be embracing the international phenomenon of IBF, the South African economy may deprive itself of significant potential for direct foreign investment.

\section{Banking Association of South Africa}

As the industry representative body, the Banking Association continuously interacts with various government departments, consumer bodies and other interest groups regarding banking issues. It seeks to ensure that its members maintain best international practice. It is important to note that the Banking Association of South Africa has now also formed a working group investigating ways to bring Islamic banking into the mainstream South African commercial framework. ${ }^{29}$

\section{Financial Services Board (FSB)}

The Financial Services Board is a unique independent institution established by statute to oversee the South African Non-Banking Financial Services Industry in the public interest. The FSB is committed to promote and maintain a sound financial investment environment in South Africa. Furthermore it is important to note that the FSB has now formed a working group on Islamic finance and Islamic banking. They have developed a questionnaire for intermediaries with a view to investigate Islamic products such as sukūks. ${ }^{30}$

$28 \quad$ Vahed M A: Compliance Officer Albaraka Bank Ltd (Head-office Durban) Interview date: 20 August 2009.

$29 \quad$ Ibid.

$30 \quad$ Ibid. 


\section{Challenges in SA legislation}

The significant challenges that lie ahead for the immediate enhancement of IBF development in South Africa is perhaps appropriately based upon the issues raised on behalf of Islamic banking at the recent meeting called by the Treasury department of the SARB with Islamic finance and banking institutions in June 2008.

Until as recent as 2008 Albaraka Bank Ltd was subjected to a capital adequacy ratio of $15 \%$, the industry norm was $8 \%$. The Basel II capital adequacy ratio is pegged at $11 \%$. This issue was positively resolved pursuant to an independent audit instituted by SARB. The ratio is now reduced to $9 \%$, in line with the current ratio for all banks. Interestingly though the bank was still advised to voluntarily raise it by a further $2 \%$.

A perennial dilemma to IBF players in the conventional arena is the inevitable involvement in interest. Islamic banks are required to lodge $6 \%$ of their liquid assets with the Treasury Department in bonds which attract large sums of interest. Sukük Certificates as an alternative to Treasury bonds was suggested. The suggestion generated substantial interest. The fact that the Financial Services Board, as referred to above, has, in fact, embarked on practical steps to gain understanding of Islamic financing tools such as șukūks, is encouraging.

At the micro level, legal challenges remain due to the specific nature of Islamic products. As a result, Islamic financing products are mostly misunderstood by the customers as they tend to do "apple to apple" comparison between Islamic and conventional banking systems. Take mushärakah, for example, if it were to be regarded as a partnership under South African law, the registration of a new company would be required for every mushärakah deal - a process that may take up to two months at a time. Then there is the complication of double registration of title under a mushärakah or muräbahah property transaction. The law makes no distinction between 'beneficial' and legal title. So, of course, the property or asset is registered in the name of the client from the outset, in order to avoid duplication of the substantial costs related to transfer of ownership. For the bank's protection a mortgage is registered over the property in favour of the bank, which is then cancelled upon final payment. It is this kind of legal difficulty that gives rise to what could perhaps be described as yet a serious challenge to IBF to be overcome in South Africa. Up until now, there has been a muted opposition to IBF from some 'ulam $\bar{a}$ ', challenging the concept 'Sharì'ah 
compliance' itself. But these were mostly from individuals who enjoyed the reputation of opposing almost everything. Of late, however, two prominent muftis (jurisconsults) who enjoy wide popular support in the north have begun to openly criticise IBF. It remains to be seen to what extent this may be an obstacle for IBF development.

\section{CONCLUSION}

Whilst there is currently no legislation in South Africa that caters for Islamic banking and finance, there is definite movement in that direction. By forming working groups to investigate ways to integrate and apply Islamic banking and finance, the FSB and the Banking Association of South Africa have clearly indicated their intention to find ways in which to accommodate Islamic Banking in South Africa. This initiative appears to be further consolidated by more positive development in the development of Islamic Finance such as the launch of the JSE Sharī'ah investment index followed by the launch of the FTSE/JSE Sharīa ah Top 40 Index in 2008.

Whatever the reasons for the change in attitude by SARB and other legislative organs, it can only augur well for IBF in South Africa. There is, however, still a significant lag at product development level compared to many other countries. Șuküks, for example, have effectively been in operation in international markets for over two decades and yet to be launched in South Africa. At the same time, Islamic educational institutions and the Dārul Ifta's attached to the informal judiciaries must remain abreast, if not take the lead, in IBF research and development in South Africa. It would certainly be in their best interest to shape the future of IBF themselves instead of the conventional banks, whose motives, naturally, are restricted to profits.

Whilst the issue of different madhhabs do ordinarily represent a significant obstacle to consensus on issues of national concern, there thankfully appears to be a distinct openness in approach to opposing viewpoints in IBF (aside from the opposition recently observed as mentioned above) among followers of different madhhabs. This attitude is certainly recommended and indeed required, if IBF in South Africa, intends to lead regionally and on the continent. Given the prevailing context, the overriding outlook should take its lead from the fiqhī maxim 'when a matter is subject to severe limitations, it allows for facilitation, but when 
normality returns exactitude is resumed' (idhā d̦āa al-amr ittasa 'a wa idhā ittasa 'a $\mathbf{d a} q a$ ). This desired modus operandi will naturally gain momentum if local institutions maintain a synergistic approach with cutting-edge discourses internationally. 